University of Rhode Island

DigitalCommons@URI

Open Access Master's Theses

1982

\title{
INFLUENCE OF THE FEMALE CIRCUMCISION CONTROVERSY ON KIKUYU-MISSIONARY RELATIONS
}

Martha Kasaian

University of Rhode Island

Follow this and additional works at: https://digitalcommons.uri.edu/theses

\section{Recommended Citation}

Kasaian, Martha, "INFLUENCE OF THE FEMALE CIRCUMCISION CONTROVERSY ON KIKUYU-MISSIONARY RELATIONS" (1982). Open Access Master's Theses. Paper 1796.

https://digitalcommons.uri.edu/theses/1796

This Thesis is brought to you for free and open access by DigitalCommons@URI. It has been accepted for inclusion in Open Access Master's Theses by an authorized administrator of DigitalCommons@URI. For more information, please contact digitalcommons-group@uri.edu. 


\author{
INFLUENCE OF THE FEMALE CIRCUMCISION \\ CONTROVERSY ON KIKUYU- \\ WISSIONARY RELATIONS \\ BY \\ MARTHA KASAIAN
}

A THESIS SUBHITTED IN PARTIAL FULFILLUENT OF THE REQUIREMENTS FOR THE DEGREE OF

MASTER OF ARTS

IN

HISTORY

UNIVERSITY OF RHODE ISIAND

1982 


\section{ABSTRACT}

The controversy over female circumcision which occurred between the Protestant missionaries and the Kikuyu tribe in Kenya during the late 1920s, severed relations between the two groups and compelied the natives to seek their own religious and educational institutions outside missionary control. It was the rigid missionary stance on the issue of female circumcision which led to the establishment of the independent churches and schools in Kenya, and hence contributed to the growth of Kikuyu nationalism. The purpose of this thesis is to examine tine reasons why the female circumcision controversy occurred, the nature of the problem, and its contribution to the rise and spread of Kikuyu nationalism.

The European missionaries did not adhere simply to their principal vocation, that of converting the natives, but insisted also on a total transformation of the whole social and cultural structure of Kikuyu society to conform to European standards. The "barbaric" custom of female circumcision was to have no part in this transformation. The Kikuyu argument was not in defense of the actual surgical operation. Rather, they contended that the operation was the basis of the institution of initiation, an 
institution which had enormous educational, social, moral, and reifigious implications, quite apart from the operation itself.

Events leading to the crisis of 1929 will be presented chronologically. African reactions to missionary policies will be shown, and larger implications of the controversy will be presented. Hissionary demands for the eradication of the ceremony and total cultural transformation of native society were a deciding factor in the rise of kikuyu nationalism, which would culminate in the liau Mau revolt of 1952-1960. This revolt, of course, hastened Kenyan independence. 


\section{TABIE OF CONTENTS}

CHAPTER

I. MISSIONARY OCCUPATION OF KIKUYUIAND........ 1 CHAPTER

II. JVISSIONARY EDUCATION AND NORAI STANDARDS.... 12 CHAPTER

III. THE RITE OF INITIATION.................. 26 CHAPTER

IV. GROWTH OF THE CONTROVERSY OF 1929......... 38 CHAPTER

V. INDEPENDENT CHURCH AND SCHOOI VOVEVENTS..... 62 CHAPTER

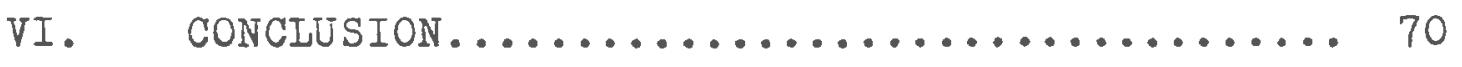

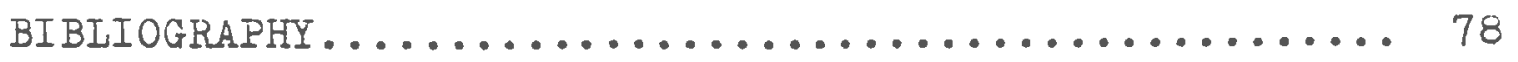


MISSIONARY OCCUPATION OF KIKUYULAND

East Africa, prior to the advent of the Europeans, had been an important trading center dominated by Arab merchants. During the fourteenth century, the great Islamic states of Egypt, Arabia, India, and Indonesia were all-powerful in the Inaian ocean. They controlled the trade between the East and medieval Europe, a trade in which East Africa, with its ivory and gold, played an important part. By far the greatest value of East Africa, however, was the market it provided in slaves, which were considered essential to the Muslim way of life. Enslavement of Muslims was prohibited in the Islamic world, thus the demand for East African slaves ran high.

East Africa provided an inexhaustible supply of slaves, and by the fifteenth century the Arabs had established a number of trading ports along the coast. These ports were, in effect, autonomous city-states which often feuded with each other. It was this feuding which prevented an extensive colonization of the area by the Arabs.

Arab prosperity was at its peak in 1497 when the Portuguese explorer Vasco da Gama rounded the southern tip of Africa and made his way up the coast of Mombasa. The Portuguese were searching for some means of reaching the Eastern markets by outflanking the strong forces of 
Islam. Eight years later the Portuguese were able to claim the whole of the Coast and the trade route to India because the East African city-states were divided among themselves and unable to deal with a common enemy.

Portugal never made a profit out of her sast African dominions and gradually, after the sixteenth century, the East African ports lost their importance to Europe. Until about 1870, Europe knew almost nothing about the interior of Africa. There were other reasons, besides ignorance, for Europe's neglect of its colonial opportunities.

Two of the great colonial powers in the twentieth century, Germany and Italy, did not exist until the second half of the nineteenth. Each was a group of independent or semiindependent states. The Italian states joined together between 1860 and 1870, and the German states in 1871. Belgium was a tiny country and would never have thought of becoming a colonial power had it not been for the energy and ambition of King Leopold II. 1

Great Britain was also not interested in the idea of African colonies. There were several reasons for this. One reason was that Britain had already lost the colonies which were to become the United States, and tended to assume that sooner or later she would lose Canada, Australia, and

W.E.F. Ward and I.W. White, East Africa: A Century of Change 1870-1970, (New York: Africana Publishing Company, 1972), p. 13. 
New Zealand as well. This feeling was strong in Great Britain until the $1870^{\prime} \mathrm{s.}^{2}$

A second reason for Britain's lack of interest in African colonies was that Britain did not need colonies for trade purposes, for her trade was flourishing without them. Britain led the world in the invention of new machinery and new industrial techniques. Until 1875 no country could compete with British goods. Thus, as long as Africa was free to buy whatever it wanted, it would buy British goods, since they were the cheapest and the best. It was in British interests to keep Africa open freely to European trade; then British goods would sell freely in Africa.

A third reason was that British capital and siki=il had openings in North and South America, as well as in Australia, New Zealand, and India. All these countries had great trading potentials. Africa was unknown, and seemed to have little to offer. ${ }^{3}$

For these reasons, Britain steadfastly refused to increase her colonial responsibilities in Africa. This view, however, was to change in the nineteenth century as Africa became the object of colonization, at first by Belgium and Germany

... who had not previously shown any interest in the continent. It was this that upset the preexisting balance of power and influence and pre-

$$
\begin{aligned}
& 3 \text { Ibid., p. } 13 . \\
& \text { Ibid., p. } 14 .
\end{aligned}
$$


cipitated a state of international hysteria in which all the powers rushed to stake claims to political sovereignty and to bargain with each other for recognition of this or that region. 4

With the growing interests of Belgium, Germany, and France with the establishment of a German protectorate over Tanganyika, British interest in colonization beightened. The ultimate goal of all British designs on East Africa was to secure a route to India and the East. 5 When the Suez Canal opened in 1869, interest in Egypt both as a trading port and as a means of passage to India increased considerably. Because Egyptian commerce relied heavily on the Nile River, control of the source of the Nile became of paramount importance to Britain, and the source was in Uganda. Thus Gladstone's occupation of Egypt in 1882 not only emphasized British concern for the Canal and the route to India, it also underlined the strategic importance of Uganda. 6 Increasingly, East Africa in general and Uganda in particular came to be seen as an essential part of Britain's overall strategy.

As a result of acquiring Uganda as a protectorate, the British government had to establish a settled administration to pay for services. This meant that the resources of the

\footnotetext{
Roland Oliver and J.D. Fage, A Short History of East Africa, (Baltimore: Penguin Books, 1962), p. 182. G.H. Mungeam, British Rule in Kenya 1895-1912, (Oxford: Clarendon Press, 1966), p. 7 . 6 Ibid.
} 
country had to be developed. To improve communications, a railway, started in 1896, was built from the port of Mombasa on the Indian Ocean, through the East African Protectorate, later called Kenya Colony, and on to Lake Victoria. The building of the railway was the beginning of major British involvement in Kenya.

Once in occupation of Kenya, however, they were under relentless pressure to develop the resources of the colony, if only to make it seif-supporting. 7 Because the country was sparsely populated and without obvious mineral resources, a succession of British governors encouraged immigrant European families to settle in Kenya and develop an economy based on the export of cash crops. These settlers were encouraged to create a virtual "white man's country." AII governmental policies were developed to that end. 8

The central highlands of Kenya were where the majority of the immigrants settled. This region was also the home of three African peoples-the Kikuyu, the Kamba, and the Nasai. These people did not welcome European colonization and settlement in their homeland. Early resistance was based upon the use of natives in forced labor and the fear over loss of land. In the settler economy the role of the natives was primarily that of wage earner, for it was assumed that Afri-

Robert I. Tignor, The Colonial Transformation of Kenya, (Princeton: Princeton University Press, 1976), p. 355. 8

Carl G. Rosenberg and John Nottingham, The Myth of Miau liau: Nationalism in Kenya, (New York: Frederick A. Praeger, Pubs., 1966), p. 7 . 
cans would be more productive working for European settlers than working for themselves. There was, in addition, the belief that Africans would more rapidly become "civilized" by coming into direct contact with Europeans. 9 Among the means that were employed to create a labor force was a program of taxation on Africans. Because the Africans could only obtain the money to pay the tax by working for Europeans, the Europeans would then be gaurenteed the labor force needed to produce casi crops.

Among the natives, fear over loss of land was the base of most of the insecurity which was to play so great a part in the African response to European impact. Kikuyu Iand systems were known as githakas. A githaka is a plot of land jointly owned by the members of a local Iineage. Through epidemics and disasters, many Kikuyu had left their traditional githakas and moved on to other areas, but they did not relinquish their titles to the land. Since the Kikuyu were not there, the Europeans did not think that the land was claimed, and many settlers came to reside on those lands which were tine most fertile, and later refused to move. Since many of these Iand losses occurred in the first decade of British mule, they implanted in British-African relations an issue which was nover fully resolved. Land losses engendered such feelings of hostility among the natives that even the most innocent and beneficial British policies began to arouse

$$
\text { Ibid., pp. 20-21. }
$$


suspician and were thought to harbor ulterior and evil motives. 10

The early years of the twentieth century also saw the beginning of the "White Highlands" policy. The Europeans had been demanding the conventional right of British colonists to elect their own representatives to the Protectorate's Legislative Council. In 1905 the Colonial office assumed responsibility for the Protectorate from the Foreign Office. In 1906 a new constitution was created and the Commissioner became a Governor with Executive and Legislative Councils. The all-European Legislative Council, which first met in 1907, consisted of six Government officials and two non-officials. The Council established policy over a wide range of social and economic subjects, including land, education, and labor. In short, a colonial state was being established in which the interests of European settlers were paramount. ${ }^{11}$

The European scramble for Africa in the late nineteenth and early twentieth centuries was not only a political phenomenon but also a religious one, for along with European settlers and administrators came a new group which was to exert at least as powerful an influence on the natives as the colonial administration-these were the missionaries. Paralleling the imperial partition of the continent, a variety of missionary groups competed intensely to divide and occupy Africa for their respective churches.

10 11

Tignor, Colonial Transformation, p. 5 . Rosberg and Nottingham, Mau Mau, pp. 19-20. 
Missionaries came to East Africa for a variety of reasons, but the most important was the East African slave trade. Even though the slave trade had been prohibited, many traders were still reaping a profit by smuggling slaves illegally from the interior. Between fifty and seventy thousand slaves were being exported every year. ${ }^{12}$ British warships were catching about nine hundred of these illegally exported slaves every year; and their disposal was becoming a serious problem. Proper rehabilitation of released slaves was a difficult matter. Captured usually from the most backward tribes of all, they somehow had to be educated to survive in the comparatively advanced conditions at the coast. The problem of freed slaves did much to attract missions to East Africa, and even more to interest the British Government in missionary enterprise.

Four Protestant societies-one from the United States and three from Great Britain, originally divided the Kikuyu missionary field. Each brought different levels of commitment, different techniques of conversion, and different attitudes toward education. Moreover, the missionaries found themselves dealing with areas that varied considerably in their ability or willingness to absorb these new forces of social change, "whose principal agents the missionaries had rapidly become." 13

In order to avoid unnecessary overlapping between the work of different missions in Kenya Colony, it was agreed to aivide the accessible country into "spheres of influence."

12

Roland Oliver, The Missionary Factor in East Africa, 2nd ed.., (Iondon: Longmans, Green and Co. ITD, 1965), p. 15. 
Without doubt, this policy greatly speeded up the work of spreading the Gospel. Each mission had spheres which it, and it alone, was to proceed with the work of proclaiming the Gospel and all that it entailed. ${ }^{14}$ The Roman Catholics never accepted this principle, nor at a much later stage did the Salvation Army, but for many years there was no competition in evangelism between the missions.

In 1891, three directors of the Imperial British East Africa Company, Sir Willian Makinnon, James Bruce, and T.F. Buxton, had established a mission of their own called the East African Scottish Industrial Mission. Its only station, at Kibwezi, about 150 miles from Mombasa, served as a rest stop for officials of the Company travelling to and from Uganda. Finding the climate inhospitable and the population unreceptive, the mission moved to Thogoto, just outside Nairobi, in 1898. In 1901 the station was taken over by the Church of Scotland (C.S.M.). The C.S.M. believed in centralizing its missionary and educational activities and allowing the influence of large stations to radiate into the countryside. 15 In Kenya, the C.S.M. had three stations: at Thogoto (Kiambu district), Tumutumu (Nyeri district), and Chogoria (Erbu district). Thogoto was the largest station and the headquarters.

The Church Missionary Society (C.M.S.), began its work on the Kenyan coast in 1844; but it made no effective entry into the East African interior until 1877, when the first missionaries reached Buganda. The C.Mi.S. policy was to open a

14 Kev. W.G. Capon, Towards Unity in Kenya, (London: RegaI Press LTD, 1962), p. 7 .

${ }^{15}$ Tignor, Colonial Transformation, p. 113. 
considerable number of small stations rather than a few larger ones, as the C.S.M. had done, each headed by a single missionary or a few individuals, in order to maintain close personal contact with a large number of people. Their first station among the Kikuyu was Kabete, occupied in 1900, but their greatest influence was in Fort Hall district. At Weithaga the C.M.S. opened a mission station in 1903 and also established a station at Kahuhuia. The C.M.S. had a great deal of influence in the area surrounding Weithaga because of the rapport their agent, A.W. NacGregor, was able to establish with the people. At a time when other stations were struggling to win converts, Weithaga had already baptized fifty persons. 16

The Africa Inland Mission (A.I.N.), was another group which competed for the Kikuyu missionary field. The A.I.M., an offshoot of the American revivalist upsurge in the last part of the nineteenth century, was comprised mainly of Baptists, but also included Niethodists, Presbyterians, and Anglicans. The religion it took to Africa was strongly evangelical, Bible centered, fundamentalist, socially conservative, and concerned above all else to evangelize or "win souls to Christ." 17 In 1901 C.E.Hurlburt established a mission at Kijabe and in 1902 the Reverend C.F. Johnson opened another one at Macnakos.

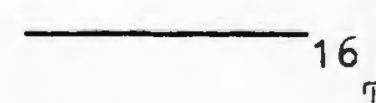
17

Tignor, Colonial Transformation, p. 113. Ibid., p. 116. 
In 1902 a Pentecostal element in this mission constituted itself into the Gospel Missionary Society (G.M.S.) but remained in the same district. In spite of the smallness of the G.M.S., it was to have an important impact on the kikuyr, for two of its converts were Harry Thuik, said to be Kenya's first nationalist, and Waru wa Kungu, an important chief.

Roman Catholic interests in East AIrica originated in connection with the Kilimanjaro missions of the Holy Ghost Fathers. Monsignor de Courmont, the Vicar Apostolic of Zanzibar, established a coastal branch for this mission at Bura, near Voi, in 1891. In 1899, however, his successor, Bishop Allgeyer visited Nairobi and established a mission among the Kikuyu eight miles to the west. Realizing that the new mission cost more money to mun than his congregation could provide, he accepted offers of help from the Consolata society oI Turin. The first Italian Fathers arrived in June 1902 and were stationed at Kiambu (1902), Limuru (1903), and Miangh, near Thika (1906). The Kenya mission remained the joint concern of the two societies until world war $I$.

Missionary development in Kikuyuland thus presented a confusing and uneven pattern. In the early days this mattered little. Fach missionary within his "sphere" was confident of his own objectives. The early pioneers, such as Reverend Harry Leakey, Reverend A.W. MacGregor of the C.M.S., Dr. Scott, A.R. Barlow and keverend J.W. Arthur of the C.S.M. built up their stations with very little money. They made converts as much by the strength of their personalities as by the power of their faith. 
MISSIONARY EDUCATION AND MORAI STANDARDS

The roots of the female circumcision controversy which would erupt in 1929 , can be traced to the imposition of European standaras of Christian morality, especially sexual morality, upon the indigenous population. This new morality was infused primarily through the mission school. From the outset, education had been seen as a primary fuction of the Christian missionary. The missionary school was always the first building constructed after the missionary chapel and missionary house.

Since education in most parts of East Africa was offerred primarily through the mission schools, the pattern of mission competition influenced the relative access to various types of educational opportunities within a given colonial territory.

In the A.I.V., particularly, there were those who thought of the purpose of missionary work as purely conversions. Thus any form of educational work which went further than enabling converts to read their Bibles was felt to be aangerous. ${ }^{1}$ A.I.M. agents were not well educated. They did not have nearly so keen an appreciation of the value of education for education's sake as did the C.M.S. and the C.S.M. In a 1912 conference held at the 
mission headquarters at Kijabe, John Stauffacher argued that eduation was "distinctly not our work except insofar as it helps us to hasten on all the more speedily that which is distinctly our work, the preaching of the Gospel to every needy creature." ${ }^{2}$ Later he was to write that "if we are simply to dirift with so many other missions into educational work, then $I_{0}$ feel very strongly that the A.I.M. will wholly miss the purpose for which it was called into being." 3

The early missionaries found the task of Christianizing the natives extremely formidable. They realized early that to have any success, it was essential that they have a working knowledge of the indigenous languages. Therefore each missionary started studying the language of his respective district. As soon as possible these missionaries began to translate parts of the Bible into Kikuyu.

Even when the language difficulties were overcome, it was not easy to persuade the people to abandon their own highly organized religious beliefs for those of Christianity. Among all the tribes of Kenya, religious beliefs and practices were so completely interwoven with their social organization that it was very hara to discern where religion began and social custom ended. 4 Realizing this,

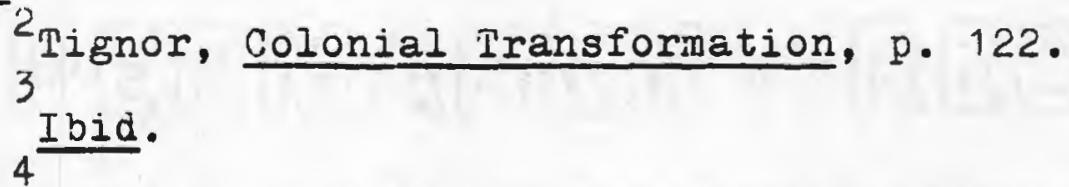
3 Ibid.

I.S.B. Leakey, Kenya: Contrasts and Probiems, (Cambridge: Schenkman Publishing Company, 1966), p. 86. 
the early missionaries felt they had to eradicate these social customs. Therefore they decreed that all who accepted Christianity must renounce these social customs. However, the very Christianity that the missionaries were endeavoring to bring to the natives was itself closely aligned with the social customs of Furope. The natives who accepted Christianity were therefore also accepting European social and cultural traditions, albeit unknowingly.

The missionaries early experienced difficulties making converts and filling their classrooms. It was not until 1908 that the G.S.M. at Thogoto baptized its first converts. Aimost all of those baptized in 1908 and the second Eroup, baptized in 1911 were individuals who had sought refuge at the mission camp during famines and remained as domestic servants of the missionaries. ${ }^{5}$ The Consolata Fathers' first baptisms did not take piace until 1911, and at the C.S.IM. station at Tumutumu it was not until 1912 that the first group of people living outsice the mission estate was baptized. ${ }^{6}$ In similar fasinion, the missions were slow in attracting young men and women to attend their schools. Even those who were eventually persuaded to go to school often deserted aiter a short while. 7

\section{${ }_{5}$}

"Report of the East African Commission," Great Britain House of Commons: Sessional Papers (April 1925), IX, p. 46 .

$$
{ }^{6} \text { Ibid., p. } 57 .
$$

Frinting School, 1933), p. 271.

(Nyeri: The Hission 
The reluctance of African parents to send their children to schools stemmed in part from the fact that the young were such a vital part of the local economy. The young herded and helped with the cultivation of crops. But equally important was the realization that the missions constituted a dynamic threat to their traditional ways of Iife. Whereas administrators tended to be concerned with maintaining political stability and therefore tried not to sponsor programs that clashed profoundly with African traditions, missionaries paid less heed to political stability and were less inclined to worry whether their programs fitted or clashed with African traditions. Actually, they sought to break with tradition, a renunciation of ways which they characterized as barbaric, primitive, and irreligious. ${ }^{8}$ Rather than trying to adapt religious and social tenets to the African environment, they held out for the full measure of their ideals among their converts. The first group of Kikuyus did not attend school because they were farsighted individuals who realized more quickly than others the economic or spiritual advantages. Schoolgoers tended to be drawn from those members of society in straitened economic conditions, outcasts from traditional society, such as twins, plus a few enterprising persons. 9

"Educational Policy in British Tropical Africa; Memoranaum Submitted to the Secretary of State for the Colonies by the Advisory Committee on Native Education in the British Tropical Dependencies," Great Britain House of Commons: Sessional Papers (March 1925), XXI p. 34. 9 Tignor, Colonial Transformation, p. 128. 
An important factor in the recruitment of school children was control over the land and the people residing on it. European missionaries in Kikuyuland had large estates and used their landholding powers to exact obedience from native families to take up farms under their authority. 10 According to the Kenya Iand Commission the total amount of land alienated to missions within the Kikuyu reserve was no less than 7,939 acres. ${ }^{11}$ These lands were acquired at the same time that settlers were taking up estates among the Kikuyu. The missions were also fully aware that their land acquisitions gave them control over the families living on these grounds.

The fullest illustration of a mission using its landholding power to facilitate school attendance was the C.S.M. mission at Thogoto. On this estate there were a large number of Kikuyu families in residence. 'As part of an effort to establish control over these families and Christianize them, the head of the C.S.M., H.E. Scott, compelled heads of families to sign an agreement to work for a certain number of days on the mission farms and to send a proportion of their children to school. Those who refused to sign were ordered to leave, and a large number of families did in fact leave. ${ }^{12}$ Much the same ocurred at the A.I.M. es-

10

"Native Affairs Department Annual Report," Great Britain House of Commons: Sessional Papers (1933), XI, p. 127.

\section{1}

12 Ibid., p. 128.

Tignor, Colonial Transformation, p. 130; from Presbyterian Church of East Africa Archives (PCEA) A/1, September 25, 1908. 
state at Kijabe where African families living on mission property had to attend chapel and work on the mission farms.

Because of Kikuyu resistance to education, the missions came to rely on the coercive powers of the state to force children to attend school. Not only did they begin to obtain funds from the state for education before 1914, but they were able to have their advanced students sign special indenture contracts obliging them to complete their term of training. Hence, if students left school before they had completed their education, the missions could turn to the state and have these students returned.

The scope of missionary influence in Kenya was not limited to Gospel teaching or academics, but encompassed the whole sector of Kikuyu physical and mental activities: of this teaching, it was the missionaries' rigid stance on issues pertaining to morality which aroused the greatest controversy and led to the cleavage of Kikuyu-missionary relations.

As previously noted, among the Kikuyu, religious beliefs and practices were so completely interwoven with their social organization that it was difficult to discern where religion began and social custom ended. Thus, to become a true Christian, a native was obliged to give up many of his social traditions, even if they had the age-old sanction of tribal custom. From 1923 onward, however, the Kikuyu increasingly began to question mis- 
sionary motives and objectives, no longer taking this authority for granted. The need to abandon tribal customs in order to become or remain a true christian began to be challenged.

The largest inhibition of all upon missionary activity in Africa was always the insistence of the Europeans, and particularly the Protestants, upon imposing their own rigid and inflexible standards of morality upon the indigenous population. 13 The missionaries were incapable of rethinking their own morality even when such experiences with their own converts suggested that they should at least attempt to form a compromise in their European values. They would not adapt their Christian ethics so that they would be more easily accepted in a culture which was so different from their own. The missionaries had been taught not to regard anything as positive and valuable in the life and culture of the African. ${ }^{14}$ They had been trained to apply derogatory labels to him and unless he surrendered completely on their own terms, these labels remained.

When the missionaries felt frustrated in their con-.. version attempts, they generally ascribed their failures above all either to polygamy, the liquor trade, or a combination of both. The A.I.M. and the C.S.M. forbade drinking and the A.I.M. smoking. The A.I.M. had a "for-

\footnotetext{
13

Geoffrey Moorhouse, The Missionaries, (Phila-

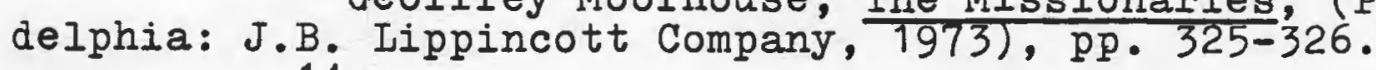
${ }^{14}$ Ibid., p. 322.
} 
nication chair" in their churches as a means of rooting out this practice. All of the missions expected their followers to give up traditional clothing-skins, rings, and beads-and to wear European clothes. Thus in the early days, Christian adherents were easy to identify.

The Catholic missions were eager to have their converts live around the mission station so that they may be physically set off from the "pagan" community. Converts were forbidden to take part in ceremonies in which "heathen rites" were practiced. This was a major reason for early hostility to mission work. Many Kikuyu ceremonies of religious worship and sacrifice to the ancestral spirits were invalid unless all the male members of the family were present. Fathers, therefore, strongly resented the wish of some of the young men to join the missions, and there were many cases where a young man lost all of his. inheritence and was disowned on becoming a Christian. 15 Once he had been so disowned, his absence from an act of family worship and sacrifice did not matter anymore.

Missionary insistence that natives adhere to European standards of sexual morality was the main reason for their failure to attract many converts during the early years of occupation. The Kikuyu had no knowledge of the Bible except what they heard directly from the missionary. Thus

I.S.B. Ieakey, Mau Mau and the Kikuyu, (Iondon: Methuen and Company, ITD, 1953), p. 59 . 
if a missionary did not condemn a custom directly, it was assumed that to practice the custom was acceptable. 16 This was to lead to some very seroius misunderstandings. After some years the missionaries considered that they knew the language well enough to translate the New Testament, but, unfortunately, they used in the translation words whose meanings, both actual and implied, were not at all those which the translators wished to convey. For example, the word "virgin," even. when used in reference to the Virgin Mary, is translated by the word mũirítu (Matthew 1,23 and Iuke 1,27). ${ }^{17}$ However, to the Kikuyu the word mũiritu means essentially one thing, an unmarried girl who has been through the initiation ceremony, and who has therefore undergone the operation of circumcision; and it further implies that she indulges in ümbani and nguiko. ${ }^{18}$ (Certain restricted forms of intercourse, called ümbani and ngữko, were not only permissible, but definitely desirable and proper for young unmarried people. These restricted forms of sexual practices may almost be described as "mutual masturbation"). It should be added that in their oral teaching, although not in the translations, the Virgin Mary was described as a mûirĩtu mũtheru, or clean nûtheru, and that, whenever possible, those among the missionaries who realized how much the translation fell short, did try

\footnotetext{
p. 89 . L.S.B. Leakey, Kenya: Contrasts and Problems,
} 17 18 Ibid., p. 76. Ibid. 
to explain something of what was meant by the word "clean." But even when explanations of some sort were given by the missionaries, no such explanations were attempted by most of the village teachers and catechists, nor was any explanation available for the ever-increasing number of natives who were self-taught, and who read the New Testament without anyone to explain it to them.

In almost every tribe in Kenya, because there are many more women than men, polygamy is accepted as a common practice. Although only a small percentage of men have more than one wife, the fact of polygamy means that every woman can have a husband. To the African woman there is nothing more terrible than the idea of being unmarried, childless, and a virgin all her life. ${ }^{19}$ Thus the practice of polygamy arose as a solution to the problem of the scarcity of men. From the earliest days, polygamy had been taught as being un-Christian. As Kikuyu knowledge of the Bible increased, however, many began to question this tenet. It was discovered that Abraham, David, and many others had more than one wife. When asked about this, the missionaries asserted that polygamy ocurred before the birth of Christ. While Christ did not actually state that polygamy was sinful, His teachings implied it, and the Church had deduced it. ${ }^{20}$ To be a Christian, one must obey the laws of the Church. Thus the Protestant churches insisted

\footnotetext{
Leakey, Kenya: Contrasts and Problems, p. 92. Ibid.
} 20 
that a male convert take only one wife. They also demanded that a female convert not marry a man who had another wife. The natives did not follow this law closely, and during one visit to the Kikuyu, Bishop Weston of Zanzibar had to adjudicate five hundred cases of what were euphemistically called "marriage offenses." When he returned in later years the number had risen to one thousand, and half of them were thought to be so serious that the offenders were not allowed back into church communion. 21

In some respects the most revolutionary aspect of European contact with Africa lay in the Christian attitude towards the initiation ceremonies and the practice of female circumcision. It was European condemnation of this custom which aroused the greatest outcry from the natives and caused overt opposition to mission teaching. The Kikuyu argument lay not in the defense of the actual surgical operation or its details, but in the understanding that the ceremony constituted the basis of an institution which had enormous social, educational, moral, and religious implications to the natives. The initiation of both sexes. was the most important Kikuyu custom. It was looked upon as a deciding factor in giving a boy or girl the status of an adult. To be uncircumcised is to be the general laughing stock of the community.] An insult very much resented by a Kikuyu is to be called kahè, an uncircumcised boy. ${ }^{22}$ No proper Kikuyu would dream of

21

Moorhouse, The Missionaries, p. 326. ${ }^{22}$ Cagnolo, The Akikuyu, p. 83. 
marrying a girl who was not circumcised, and vice versa. It is also forbidden for a man or woman to have sexual relations with omeone who has not undergone the operation.

The initiation ceremonies also mark the commencement of participation in various governing groups in society. All men and women had to be circumcised before they were ritually fit to be tribal members. An age-set comprised all those circumcised at the same time. The nembers of this group

stand in the very closest relationship with each other. When a man of the same age-group injures another it is a serious magico-religious offence. They are like blood brothers; they must not do any wrong to each other. It ranks with an injury done to a member of one's own family. 23

What occurs here is that the initiation ritual formally established a pseudo-kinship among age-mates. Upon meeting one another, the expression of salutation is wanyua-wa-kiine, my tribal equal. 24 within various districts these sets carry out almost all social functions as a corporate group. For instance, pre-marital sexual intercourse (ngweko) with circumcised girls occurred in a common hut where switching partners was an accepted practice. This practice is supposed to prepare the participants for polygamy and also establish a normative pattern which allows age-brothers to have inter-

23

Jomo Kenyatta, Facing Mount Kenya (New York: Vintage Books, 1962), p. 115 . 24

Rosberg and Nottingham, Mau Mau, p. 150. 
course with each other's wives without breaking the customary law or arousing paternal jealousy. 25 In general, the relationship between men of the same age grade tended to stress their shared and equal attributes.

Another reason for the importance of the initiation ceremonies is that in Kenya, time is measured not by years, but by age-groups. The history and legends of the people are explained and remembered according to names given to various age-groups at the time of the initiation ceremony. For example, if a devastating famine occurred at the time of the initiation ceremonies, that particular initiation group would be henceforth known as "famine" (ng'aragu). In the same way, the Kikuyu have been able to record when a number of maladies, such as syphilis, entered Kikuyru country, for those initiated at the time when this disease first showed itself are calied gatego, ie. syphilis. 26

Historical events are recorded and remembered in the same manner. Without the initiation ceremonies, a tribe which had no written records would not have been able to keep a record of important events and happenings.

Thus, with the advent of the European missionaries, and their insistence on the eradication of this ceremony, traditional life threatened to be permanently disrupted. It

25 26

Kenyatta, Facing Mount Kenya, pp. 157-158. Murray-Brown, Kenyatta, p. 129. 
was the Kikuyu desire to preserve its national customs, especially the initiation ceremonies, which led to the controversy of 1929 and became the basis for the rise of the Kikuyu Independent Churches and Schools. 
THE RITE OF INITIATION

One of the most important events in the lives of the Kikuyu is the ritual that marks the passage from childhood into adulthood (and consequently, the formal initiation into the tribe). In order to better understand the significance of this rite of initiation, of which the outward sign is circumcision, it is necessary to examine this ceremony in detail.

The available descriptions of Kikuya initiation rites are confusing and very different. The chief reason for this, apart from the fact that most of the descriptions are apparently based on the observation of only one, or even only part of one ceremony, ${ }^{1}$ is that the same rite is also practiced by other Kenyan tribes, namely the Masai, with some alterations. The physical operation is the same in both cases, but the remainder of the ceremony is quite different. In addition, each clan practices a somewhat modified version of the basic rites. ${ }^{2}$ certain customs, however, appear to be common in all the different tribal and clan versions.

John Middleton and Greet Kershaw, The Central. Tribes of the North-Eastern Bantu, East Central Africa Series of the Ethnographic Survey of Africa (Iondon: International African Institute, 1965), p. 56.

$$
{ }^{2} \text { Ibid. }
$$


Initiations usually take place yearly, unless crops have failed or there are some other signs of divine displeasure. 3 They are held at the beginning of the wet season, when the crops have been sown and before they are gathered; at this time little labor is needed in the fields. The ceremonies cannot begin at full moon, since this would be unlucky. ${ }^{4}$ H.R. Tate says that boys and girls are initiated at different months and during different rains; ${ }^{5}$ on the other hand, K.R. Dundas states that both sexes undergo the ceremony in the same months, but that the season:depends on whether they live in east or west Kikuyu. ${ }^{6} \mathrm{~J} . \mathrm{A}$. Massam states that initiations are regulated by the constellation Aquilae:

The two most prominent of the four visibie stars in that group are said to be a warrior and his wife, the two less brilliant stars being their children. The wife always appears first, accompanied by one child. One year the wife appears in the east. The next year she is in the west, one child accompanying her. Should she be seen at any time entirely alone, she is believed to be on a search for food, and famine will occur that year. At such times clitoridectomy may not be performed, otherwise

\section{Ibid., p. 56 . $5^{\text {Ibid. }}$}

H.R. Tate, "The Native Law of the Southern Gikuyu of British East Africa," Journal of African Society $110(1911): 285$.

6

H.R. Dundas, "Kikuyu Calendar," Man 9 (1909):38. 
starvation will be certain. When the wife is seen with her husband in the east, the season is propitious for the operations. 7

After the coming of the Europeans it became a common practice for Kikuya boys to go through the initiation ceremonies and the circumcision operation at about the age of fourteen or fifteen. This was not the case before the coming of the white man, when no boy. was allowed to undergo initiation until he was at least seventeen or eighteen years old. 8 To allow-a boy of less than seventeen or eighteen years to be Initiated wauld have: been: unwise for, once initiated, be would become a full member of the fighting forces of the tribe, responsible not only for defense, but also for attacking the Masai and other enemies. 9 Girls, on the other hand, were supposed to be initiated before the onset of memstruation.

The actual initiation ceremonies may be regarded as commencing on the day of the matuumo, the day before the circumcision operations. This was the day upon which all the candidates assembled for the first time at the homestead of the mûruithia, where the ceremonies would take place, and are "adopted" by the murruithia and his wife. 10

J.A. Massam, The Cliff Dwellers of Kenya, (London: Frank Cass and Company, ITD, 1968), p. 56. 8 1903, 3 vols., (Iondon: Academic Press, 1977), Vol. 2 , p. 587 .

$$
{ }_{10}^{9} \text { Ibid., p. } 588 .
$$

Middleton and Kershaw, "Tribes of the Bantu," 
On this day the village medicine-man sets up the "altar," purifies the homestead, and recites charms to protect it and its inhabitants from all baneful influences and evil. ${ }^{11} \mathrm{~A}$ gateway, or arch of sugar canes and banana tree stems is constructed outside the homestead through which every person who came into the homestead has to pass, so that if anyone who entered had any evil influence attached to him or her, the evil would be destroyed. 12

While the medicine man and the advisors are busy with their preparations on the morning of the matuumo ceremonies, the candidates arrive accompanied by their friends and relatives. As each party arrives, they first have to enter the courtyard of the homestead, and so pass through the gateway that purified them. Then, after dancing a few minutes in the courtyard, they go out to the entrance area and start dancing there, and this dancing continues until every candidate has arrived.

When all the candidates had assembled, they were taken to the area where a few members of the muruithia's family were preparing sugar-cane juice for beer, to be used for njohi ya murungu (ceremonial sugar-cane beer). Each candidate was given a chance to squeeze the juice or pound the pulp of the sugar cane, so that each might have a part in

\footnotetext{
11 12

Leakey, "Southern Kikuyu", p. 608. Ibid., p. 609 .
} 
the preparation of the njohi ya murñngu. 13

Meanwhile, according to Kikuyu custom, a goat had been. slaughtered by strangulation in the courtyard, and while it was being roasted, the skin was cut into rawhide strips. The candidates were then summoned into the courtyard. Now the muruithia, assisted by his advisors, put one rawhide strip onto the right-hand middle finger of each male candidate. These rawhide strips were so long that after being slipped over the finger, the "tail" of the strip was wrapped around the boy's wrist. Meanwhile, the wife of the muruithia, with the help of the wives of the advisors, twisted one of the rawhide strips into anklets and put them on the left ankle of each female candidate. This was to prevent any girl from being so unfortunate as to have her first menstrual period during the initiation ceremonies. ${ }^{14}$

The candidates then leave the homestead and go to a nearby sacred múgamo tree; the girls walk first, and the boys race. Great honor was attached to the boy who won this race, because he was destined to become one of the leaders of the initiation age-group in his particular territorial section. ${ }^{15}$ Upon arriving at the tree, each boy

\footnotetext{
$\longrightarrow 13$

14 Ibid., p. 613.

Kenyatta, Facing Nount Kenya, p. 131. 15

C.W. Hobley, Bantu Beliefs and Magic, (New

Yorik: Barnes and Noble, 1957), p. 81.
} 
had first of all to fling his club over the tree, and then throw his staff over the branches. ${ }^{16}$ Should he do either of these things clumsily, with the result that his club or staff got stuck up in the tree, it was a very bad omen for his future, and he was certain to die young, and he would probably die a violent death. ${ }^{17}$

Meanwhile, the girl candidates, who were on no account allowed to run to the tree, had been escorted to it by their two female sponsors. Having arrived at the tree, the sponsors proceeded to strip bark from the branches. Each male sponsor now took five mügumo leaves, and one of the female sponsors of each girl took four. ${ }^{18}$

Hobley's interpretation of this ceremony is a bit different. As the candidates approached the mügumo tree, the boys threw clubs and sticks up into the tree, and then commenced to climb into the branches, hacking the whole time at the leaves and twigs; each youth had a light club with the head sharpened to a blunt cutting edge, and by vigouous hacking gradually broke off small branches which fell down among the crowd below, and were immediately seized by the people. The people then danced around the tree, and thus ended the proceedings. ${ }^{19}$

\footnotetext{
$\longrightarrow 16$ 17

Kenyatta, Facing Mount Kenya, p. 135. 18

Leakej, "Southern Kikuyu", pp. 615-616. 19 Ibid., p. 616. Hobley, "Bantu Beliefs", p. 82.
} 
As soon as the candidates arrived back at the homestead the mũruithia, his wife, the advisors, and their wives produced the honey beer brewed the night before. They each took a mouthful, and, retaining, their mouthfuls, passed it on. At the signal from the murruithia, they sprayed the can-... didates with the beer that was in their mouths. 20 This spraying of the ceremonial beer was the most solemn form of blessing that it was possible to give. ${ }^{21}$

On the morning of the actual operation, when the candidates arrived at the müruithia's homestead, they were sent off to the nearest stream to bathe under the supervision of some warriors and older girls. Each candidate had to sit down in the cold running water, so that his or her genitalia were completely numbed by the cold. Besides numbing them with cold so that the operation would be less painful, the object of the bath was so that they went into the operation clean and fresh. 22

While the candidates had been bathing, their sponsors each collected the bunch of mūgumo leaves belonging to his or her charge and went to the operating site, a grassy patch of ground that had been selected for the purpose. Here they assembled to await the arrival of the boys and girls.

Kenyatta, Facing Mount Kenya, p. 137. 21 22

I- akey, "Southern Kikuyu", p. 617.

Ibid., p. 619 . 
When they arrived, the girls were taken to one part of the field and the boys to another. Unlike the Amwimbe, who do not separate, the Kikuyu consider it highly improper for any young boy or man to witness the circumcision of girls. 23

The boys sit down in a row facing Mount Kenya, in their order of seniority, and each sponsor takes his position behind the boy he is supervising, so as to give him something to lean against. A large number of friends and relatives form a circle around the boys to watch for any signs of fear on the part of those carididates in whom they are interested. Each boy must remain perfectly silent during the operation, as any who cry out are branded for life as cow$\operatorname{ards} .24$

The two operators, and man and a woman who had come to perform the actual operations were known as aruithia (plural of murruithia, but not to be confuged with that of the man whose home the initiation was centered). The only task of the operators was to perform the actual. operations and treat the wounds.

As soon as all the boys were seated in the correct position, the operator seized the senior boy's prepuce with his left hand and inserted his forefinger into the opening in his foreskin, after pulling it forward and stretching it

G. St. Orde-Brown, "Circumcision Ceremonies Among the Amwimbe," Man 13(1913): p. 137.

24

Hobley, "Bantu Beliefs", p. 68. 
to its limit. He then cut a slit across the back portion of the prepuce on the upper surface and at right angles to the penis. Having made this slit, he brought the glans penis through the slit so that it was exposed. Unlike the Amwimbe who remove the skin altogether, the Kikuyu do not cut the foreskin off, but leave it below the glans penis, where it remains for the rest of his life. 25

When the operator had been down the line once, circumcising each boy quickly, he came back to the senior boy and proceeded to go down to the end of the line a second time, examining the wounds. As soon as the boy had been thus examined, his sponsor took a special cloak (nguo ya maribij), put it over his charge, and escorted him to another corner of the field where a fire had been lit for the initiates. The boys were now no longer $\underline{i h \hat{i}}$ (uninitiated boys), but irui (initiates), a title which was theirs until the end of the period of seclusion and training, when they would become novices (ciumiriri). 26

There is a certain amount of conflicting evidence as to the details of the actual physical operation of the girls, and this is probably due to the existence of slight variations of the operation from district to district. The

\footnotetext{
25 p. 138 . Orde-Brown, "Circumcision Among the Amwimbe", 26 Ieakey, "Southern Kikuyu", p. 622.
} 
operation itself entailed a cutting away of the clitoris, the labia minora, and half the labia majora.

The operation on the girls took place in a separate part of the field from the boys. First, the girls' mügumo leaves were placed down on the ground, and the senior sponsor sat down in such a way that these leaves were between her outstretched legs. She then dug her heels into the ground to get a firm grip. The girl candidate was made to sit on her sponsor's legs above the knees and put her ankles under the knees of her sponsor. She thus had a very firm seat, slightly raised off the ground, the reason for this being that unless she was thus raised, the operator could not work properly. 27

The senior sponsor, then put her arms under her charge's armpits and around her chest to hold her tightly, while the second sponsor took up a position behind the first one so as to give support to her back. The girl's face was lifted toward the sky so that she would not be able to see what happened to her. ${ }^{28}$ when all the girl candidates. were in position and ready in line in their order of seniority, the female operator parted the labia majora of the first Eirl and took hold of the clitoris between the thumb and first finger of her left hand. Pulling it forward as much

Ibid., p. 622.

Kenyatta, Facing Mount Kenya, p. 140. 
as she could, she cut off a tiny portion of the skin. The clitoris was called kang'uthu or sometimes kang'ura. Sometimes the operator cut off a tiny portion of the labia majora on either side of the clitoris. In its severest form, the cutting extended in front up to the pubis and into the birth canal itself. 30 As soon as the operator had finished, the sponsor on whom the girl was sitting, clapped one hand over her eyes to prevent her from seeing the other girls being operated upon. The other sponsor then slipped a new cloak over the girl and examined the wound. There was no regular second examination by the operator, as in the case of the boys, but if the sponsor thought that there was any need to do so, she could call the operator to come and examine the sound after all the others had been operated upon.

As soon as the blood caused by the operation started to congeal a Iittle, the sponsor wiped it away. with her fingers to prevent it from drying over the wound. She then took a small quantity of mũgumo bark which she had been chewing in her mouth, and put this over the wound to act both as an absorbent and astringent. 31

In most cases the wound would heal quickly with no complications, but in each district there was almost always

29

30 Leakey, Southern Kikuyu, p. 622. 31 Kenyatta, Facing Mount Kenya, p. 140. Leakey, Southern Kikuyu, p. 623. 
a few cases of subsequent septic poisoning. 32 This would mean that the wound would take a very long time to heal, and when it eventualiy did so it left a large area of scar tissue. Such scars made childbirth difficult and sometimes fatai. 33 .

At the end of this day the initiates go through a period of seclusion which lasts approximately eight days. During this period both boys and girls live together in a specially erected hut, and they learn ritual and practical instruction on their new roles as adults.

Thus, among the Kikuyu, the circumcision of boys and girls formed an important part of the initiatory rites associated.with age-sets and entry into full membership in the tribal community. It was looked upon as a deciding factor in giving a boy or girl the status of an adult. Female circumcision was the outward symbol of a girl's reaching the end of her education and marked her readiness to indulge in sexual activities. It was impossible to imagine an initiation ceremony without circumcision. Therefore the abolition of the operation meant the abolition of a whole institution. 34

32 33

Kenyatta, Facing Mount Kenya, p., 147.

I.S.B. Ieakey, "The Kikuyu Problem of the Initiation of Girls," Journal of the Royal Anthropological Institute of Great Britain and Ireland 61 (1931): p. 279. Murray-Brown, Kenyatta, p. 128. 
It was missionary opposition to the initiation ceremonies which formed the basis of the controversy of 1929 . Early Christian opposition was based on moral and religious grounds. The public nature of the ceremonies and the overt displays of sexuality offended the puritan conscience of many missionaries. According to the missionaries, the initiation ceremonies were "extreme and immoral" and often: involved "crude examples of sexual vulgarity." 1 At an early date the missionaries taught their adherents not to attend the initiation dances because of the abscene songs sung there, and young girls were encouraged not to be initiated. Significantly, one of the early forceful statements against female circumcision was a resolution sponsored by a united Conference of Kenya missionary societies, which met at Thogoto on July 8, 1918. The statement was drawn up by a special committee sponsored exclusively by medical missionaries. It condemned clitoridectomy as "in all instances purposeless and useless, while in some districts it is highly dangerous and barbarous... and ought to be abolished. ${ }^{2}$

The C.S.M., A.I.M., and G.M.S. early sought to use the powers of the church to attack clitoridectomy. On July 16,

Tignor, Transformation of Kenya, p. 236. 2 Ibid. 
1916 the C.S.M. forbade female circumcision within the church and in 1922 they decreed that if members circumcised their daughters, they would be suspended. The majority of the Kikuyu took this to be an attack on an age-old custom which was considered essential to the welfare of the tribe, since, without initiation, girls could not become full members of the tribe, nor, by Kikuyu custom, were they eligible for marriage. 3 only a circumcised girl could be considered fully a woman. It was widely believed that uncircumcised girls would not physically be able to bear children. Not to be circumcised was to be debarred from developing the personality and attributes of womanhood and to be condemned to remain psychologically a little girl (irigo) forever. ${ }^{4}$ In Kikuyu eyes, an uncircumcised girl of marriageablekage was an object of derision, almost of disgust. The operation symbolized the most important moment in a girl's life.

Realizing that the church had only limited powers to eradicate the practice, the mission leaders looked to the state for assistance. From the earliest days, the Protestant missions had made constant appeals for Government support and encouragement in stamping out the custom." The Kenya Government likewise opposed female circumcision, and Leakey, Mau Mau and the Kikuyu, p. 89. 4 Rosberg and Nottingham, "Mau Mau", p. 112. 
described it as "horrible mutilation" and a "horrible practice, one of a number of barbarous ordeals practiced by the natives." 5 Government action in the form of legislation, however, was deemed inappropriate on the grounds, apparently, of unenforcibility. $\vec{b}$ Government officials, hesitant to interfere with such an intimate and central aspect of Kikuya life, counselled the missions to be patient. Officially, the administration took the view that only education and time would see it wholly eradicated. Administrators were rightly worried lest coercive legislation provoke opposition and accelerate nationalist sentiment. In missionary opposition, medical and hygenic concerns loomed large. The operation of female circumcision, the medical missionaries claimed, impaired the functions of urination, menstruation, and child bearing; hence they referred to the operation as "sexual mutilation."7

Whereas traditionally the operation on the girls at initiation could only be performed by professionals (aruithia), who had served a long period of apprenticeship before being allowed to perform the operation themselves, in the early twentieth century, especially in or near the townships, women who called themselves aruithia, but who had no real

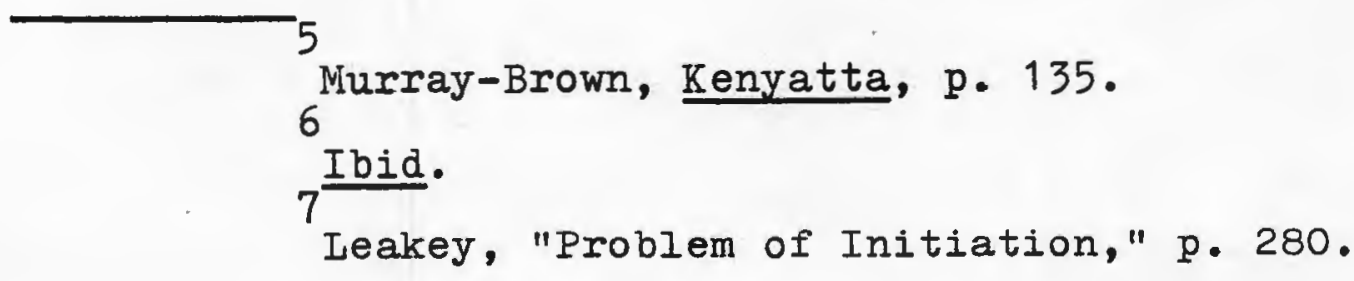


training in the profession began to perform the operation, thus increasing its severity due to lack of skill and knowledge. ${ }^{8}$ Combined with this was the fact that many unmarried girls were becoming pregnant before they reached full maturity, hence increasing the percentage of deaths in childbirth. This resulted in an everestimate by the missionaries of the percentage of deaths due to the operation at initiation. ${ }^{9}$

Around 1925 the attitude of the Kenya Government began to change from its previous hands-off policy, largely through pressure exerted Gy figure in Kenya by the 1920's. Arthur had taken over as head of the Thogoto branch of the C.S.M. in 1911 and was to dominate missionary affairs in Kenya for more than a quarter of a century. Of all the missionaries, he was the most dedicated adrocate of the eradication of the initiation ceremony, and it was largely through his efforts in this direction that the female circumcision controversy took on the magnitude it did.

Arthur was responsible for the publication of the appendix to the Fort Hall District annual report of 1925 , which contained a graphic description of the effects of female circumcision as witnessed by the assistant district

$$
\begin{aligned}
& 9 \text { Ibid., p. } 280 . \\
& \text { Ibid. }
\end{aligned}
$$


commissioner, C.E.V. Buxton. Happening upon a group of girls in a banana plantation who were "wimpering and groaning" and bleeding profusely from the just performed operation, Buxton wrote that:

an old woman kneeling between the legs (of one of the girls) spat into the wound several times and swabbed out the wound with chewed banana leaves. The girl suffered intensely, and the cries which she emitted as her wound was treated in this way denoted an agony which shatters her self control... I do not think that any thinking European who had witnessed this scene would hesitate to condemn the practice. 10

There was no doubt in his mind about the "obvious sufferings" of the girls and the futility of a passive approach towards "education." Buxton concluded his report by observing that originally he had regarded clitoridectomy

in the same light as other native customs and considered that natives should be left to change their customs when and how they liked... However, I now feel very strongly after seeing the immediate results in human suffering of this custom that the govermment should prevent it. 11

The District Commissioner, R.G. Stone, shared Buxton's views and appended to this annual report a statement by B.A.W. Proctor, medical officer in Fort Hall District. Proctor, who treated the girl observed by Buxton, said that the operation indeed was a severe one, causing "permanent mutilation and...leaving a raw wound into which half

Murray-Brown, Kenyatta, p. 136; from the Appendix to the Fort Hall District Annual Report, 1925, R.G. Stone. KNA/DC/FH/5. 11

Ibid. 
a golf ball could easily be inserted." 12

In September 1925, a confidential circular of the Native Affairs Department, issued by the Chief Native Commissioner to all provincial-commissioners stated that while legislation was still premature and action at this time might unite "native authorities against the Government in defense of old customs," nevertheless held that the time was ripe for a declaration of government policy on the issue of female circumcision. This circular stated that the government "unhesitatingly and emphatically condemns the practice." 13 Model by-laws regulating the custom were passed in many Iocal Native Councils almost immediately after their establishment in 1925. The Conference of East African Governors in 1926 decided that as the custom "was of very ancient origin" it "should be made instead to persuade tribes to abandon the more brutal forms of it and return to the more ancient and less brutal form." ${ }^{14}$ It was believed that this "less brutal form" consisted of the removal of the clitoris only, which, according to the governors, "would appear to be harmless." 15

The question of whether or not to require that only the less brutal form of the operation be performed sparked

\section{Ibid., p. 138 .}

Rosberg and Nottingham, Mau Mau, p, 113; from Circular No. 36, "Circumcision of Women," (September 21, 1925), KNA:DC/MKS 10B/12/1. 14

"Conference of Governors of the East African Dependencies-summary of Proceedings," Great Britain House of Commons:Sessional Papers (1926), XXI, p.20. 
Parliamentary debstes in the House of Commons with the result that the Chief Native Commissioner sent a circular letter to all senior commissioners requesting that if circumcision must be performed, only the milder form of the operation must be used. 16

The first such legislation of this type was passed by the Embu Local Native Council with the stipulation that no girl could be circumcised against her will. The Kitui, Kiambu, and Fort Hall Local Native Councils passed similar resolutions and only the Nyeri Local Native Council failed to enact any legislation, refusing to discuss such a private matter. Many of these new regulations, however, were widely disregarded in the reserves. 17

The crisis of 1929 would not have taken shape if it were not for the existence of a new Kikuyu political association. The Kikuyu Central Association, founded in 1924 drew its early strength from the Fort Hall district, especially around the C.M.S. stations at Weithaga and Kahuhia. ${ }^{18}$ It's members at first called their organization the Central Kikuyu Association, to stress its geographical location in central Kikuyuland. As the Association began to gain a following in Nyeri and Kiambu districts, However, they altered the name to the Kikuyu Central Association.

\footnotetext{
16

"Colonial Policy-Coloured Races," Great Britain House of Commons Parliamentary Debates, $(1929-30)$, CCXXXIII, pp. 588-591. 17 Murray-Brown, Kenyatta, p. 136. 18 Tignor, Colonial Transformation, p. 238.
} 
The K.C.A. stood as a champion of Kikuyu cultural nationalism; its members did not seek the rejection of Christianity, but the preservation of selected aspects of Kikuyu culture. Indeed, it seemed to them that it was not Christianity which was in danger, but Kikuyu culture, as the process of modernization deepened and spread across Kikuyuland. One of the aims of the K.C.A. was a more selective approach to social change.

The K.C.A. was far from a radical organization. It was suspicious of constituted authority, and apprénonsive of European designs on Kenya. In 1926, the District Commissioner of Fort Hall estimated that the K.C.A. had approximately two hundred to three hundred young and partly educated members. 19 Its Secretary at the time was Joseph Kangethe, who had been an elected member of the Fort Hall Local Native Council but was dismissed by the government. Jomo Kenyatta joined the Association in 1927 and became Secretary of the Pary and Editor of the newspaper, Muigwithania (The Unifier). 20

The K.C.A. was not a unified or disciplined political party, rather it was a loosly structured group, mainly of younger mission men, who, in varying degrees, were suspicious of European overrule. Because membership in the K.C.A.

Ibid., p. 239; from the District Commissioner of the Fort Hall District to the Provincial Commissioner, Jan 2, 1926, KNA: PC/CP 8/5/2.

Donalt I. Barnett and Karari Njama, Mau Mau From Within, (New York: Monthly Review Press, 1966), p. 37. 
was so diffuse, it was natural that it embraced a wide range of political views and contained within it a group which some Europeans inappriately called a "left wing." This term referred to those men within the $R . C . A$. Who refused to accept the government and mission attacks on pre-colonial Kikuyu traditions and asserted the integrity and virtue of these ways. In Fort Hall, irthe leading figures in this group were Joseph Kangethe, Harry Mwongi, and Job Muchuchu. Not only did they stress such standard grievances as the creation of secondary and government schools, free of missionary influence, but they also vowed to engage in female circumcision, beer drinking, and polygamy in defiance of missionary opposition. 21 In 1929, when the Fort Hall Iocal Native Council considered registering circumcisors and giving them instruction in antiseptics and hygiene, the K.C.A. members on the Council vehemtly denounced such action.

In March 1928, the question was brought up by the Government at Nyeri to discuss various problems affecting the tribe. RRepresentatives of the K.C.A. announced then their intention of contesting the forthcoming Local Native Council election on a platform of preserving tribal customs, including the circumcision of girls. This public declaration brought the W.C.A. into open conflict with the C.S.M. at Nyeri and later throughout the province.

Tignor, Colonial Transformation, p. 240. 
Following this, Church of Scotland missionaries held a meeting in April 1928 in Nyeri, with their church elders. They announced a campaign against female circumcision in the district, whose Local Native Council, alone amorig those in Kikuyu country, had refused to pass the by-laws regulating the custom. Seven of the church elders disagreed with any attempt to force the issue at that time and shortly afterward left the church. 22

The Nyeri C.S.M., from its headquarters at Tumutumu, now demanded assurances from those K.C.A. leaders that they would continue loyally to accept all the laws of the church, including one prohibiting female circumcision. In default, they would be automatically suspended. The initial response was wholesale defection, but the church retrieved the situation somewhat, and at the end of a two-year grace period only- two hundred names (or seven percent of the total Tumutumu baptismal roll as it stood in 1930) had been removed from the communion roll. 23

In opposition to the K.C.A., the C.S.M. at Tumutumu sponsored a political association of "really educated, sane men," 24 called the Progressive Kikuyu Party (P.K.P.). This party stood for the complete abolition of the initiation ceremony, including the custom of female circumcision and

$$
\begin{aligned}
& 23^{\text {Rosberg and Nottingham, "Mau Mau", p. } 115 .} \\
& 24 \text { Ibid. } \\
& \text { Ibid. }
\end{aligned}
$$


intended to put up candidates to fight the Local Native Council election on this platform. Members of the P.K.P. criticized the K.C.A. for their methods of gaining support, such as mass meetings, letters to the press, and direct petitions to the Government, and contrasted these with the moderate means of the P.K.P:

According to its constitution, it can only hold meetings in the day time; it also asks Government's permission to do so and invites local Government officials to attend. It stands for the fullest progress of the Kikuyu people, educationally and otherwise. It affirms its desire for active co-operation with men of all races in promoting the progress of Kenya Colony in general and the Kikuyu country in particular. It wishes to abolish all harmful customs such as the sexual mutilation of girls and retain only such customs as are decent... 25

Through the establishment of the P.K.P. as a rival to the K.C.A., what had begun as merely a matter of church discipline quickly became a political matter. The government now made a mistake which many British colonial governments have made. It thought that the K.C.A. did not really represent true African feeling; it was only a small group of young men, and that the true representatives of African sentiment were the chiefs and the older men. ${ }^{26}$ The government had an excuse for this mistake, however. The K.C.A. did not have very many active members, and some of the chiefs vehemently disapproved of its policy. But although only a small proportion of the Kikuyu were active members of the

Ibia., pp. 115-116; from the Church of Scotland Wiemorandum preparel by the Kikuyu Mission Council on Female Circumcision, (Kikuyu, 1931), p. 27. PRO CO 533/291. 26 Ward, East Africa, p. 100. 
K.C.A., many people heard K.C.A. speeches and were influenced by them. Moreover, the K.C.A. members belonged to an ageset which had just come into authority, and so its influence was growing. Many contemporary critics assert that the government would have been wiser to work with the K.C.A. leaders, rather than oppose them and cause the issue to become a political one. 27

In Miay 1928, at the Nyeri Local Native Council elections, each party had some success. Stanley Kiama, a young man educated at Tumutumu, stood as the P.K.P. camdidate and carried the area around. Tumutumu. Mahiga and Nyeri Township, however, elected two K.C.A. candidates.

A final and equally important factor which was to cause the crisis to erupt when it did was the fact that many of the daughters of the first generation of Christian converts were coming of age in the late 1920s. The question of whether to circumcise or not was no longer a distant and rather academic matter of church law and morality. This was a very serious problem facing Christian parents. It would appear from the rather scanty information available that up to 1929 few Kikuyu women had not beencircumcised. ${ }^{28}$ In a memorandum prepared by J.W. Arthur on August 27, 1929, he indicated that there were several uncircumcised unmarried women at the G.M.S. station at Kambui, one at Tumutumu, and two at

\footnotetext{
27 28 Ibid., p. 100 . Rosberg and Nottingham, "Mau Mau", p. 116.
} 
Thogoto. At the boarding schools at Thogoto, Kabete, Kijabe, Kambui, and Tumutumu, however, there were a number of marriageable girls, determined, according to Arthur, not to be circumcised. 29

Thus the late 1920s was a time of crisis for Kikuyu Christians, best described by the District Commissioner of Embu where the C.S.M. station at Chogoria was deeply troubled over this issue. An already fragmenting society resulting from the fast pace of social change and the erosion of old values, it was now being jolted by the new problem of female circumcision. According to District Commissioner H.E. Lambert,

the failure to circumcise was equivalent to detribalization and would further divide the Embu people into mutually antagonistic groups-the circumcised versus the uncircumcised. It would differentiate the Christians from the nonChristians and make intermarriage exceedingly difficult. The bonds of culltural unity which held together these politically decentralized and loosly structured communities in the past were being broken. 30

Kenyans would be denationalized and their heritage obliterateã, thus making them more subject and subservient to Europeans and acquiescent in their role. 31 Nany natives felt this an unforgivable breach of faith on the part of

29

Tignor, Colonial Transformation, pp. 240-241; from Memorandum by J.W. Arthur, August 27, 1929, KNA PC/ CP $8 / 1 / 1$. 30

Ibid., p. 241; from the District Commissioner of Embu to the Provincial Commissioner, Octoter 15, 1929, KNA DC/MKS $1 / 1 / 2$. 31

L.H. Gann and Peter Duignan, eds., Colonialism in Africa 1870-1960, Vol. III: Profiles of Change: African Society and Colonial Rule, (Cambridge: Cambridge University Press, 1971), pp. 443-444. 
the missions. Africans had given land to the missions and sent their children to mission schools; now their trust was rewarded by impossible demands. 32

These factors were all necessary causes of the conflagration of 1929, but they were not sufficient in themselves to account for the breakaways that occurred that year. The decisions taken by J.W. Arthur were to expand the difficulties into crisis proportions.

In March 1929 a conference of forty church elders, representing the mission stations in Kikuyuland met at Tumutumu. Among other matters, the subject of female circumcision was discussed and three resolutions passed:

... 1. Resolved, with one dissentient, that this custom is evil and should be abandoned by all Christians.

2. Resolved, by 30 to 9 , that all Christians submitting to it should be suspended by Churches everywhere.

3. The Conference makes no recommendations as to the period of suspension. It refers the question back to the churches, asking that it be carefully considered with a view to getting a definite decision at a future Conference. 33

After the conference had dispersed, the crisis flared up in Kiambu. J.W. Arthur was at the, heart of the crisis. He felt that at stake was the whole question of church discipline. For him, it was a matter of principle. The

32 33

Tignor, Colonial Transformation, p. 241.

Murray-Brown, Kenyatta, p. 136; from "Minutes of the Conference of Kikuyu Church Elders held at Tumutumu," March 8-12, 1929, CCK, file No. 57. 
Church had passed certain laws and all members should vow to obey them in accepting Christian fellowship. To oppose these laws was not just a matter of rebellion against the way the church was being run, rather it was a question of spiritual deception. Those guilty of it were sinning against their own promises and against their own souls. 34

A few months after these resolutions were passed the famous Kihumbuini case occurred. 35 This involved the forcible seizure and circumcision of a fourteen year old girl, taken from the C.M.S. dormitory at Kihumbuini. In the district commissioner's court, M.R.R. Vidal ruled that since the girl finally consented to the operation, although under enormous pressure, the only penalty the state could exact was a fine against the two circumcisors for having performed the "major" instead of the "minor" operation. This judgement was upheld in the Kenya High Court, and Arthur, who followed the case closely, was incensed by the minimal penalties and what he regarded as frivolous remarks made by one of the presiding judges in the High Court, who compared what happened to the girl with the mishaps of surgery at the barber's shop. 36

Arthur wrote an angry letter to the East African Standard on August 10, 1929. This letter produced an immediate K.C.A.

\footnotetext{
34 35 Ibid., p.:137. Rosberg and Nottingham, Mau Mau, p. 117; from Kiambu District Commissioner's Criminal Case No. 1 of 1929, "The Political Situation," KNA: DC/MKS 10B/12/1. 36 Ibid.
} 
response. Joseph Kangethe wrote a personal note to Arthur stating that the Europeans had no business intervening with Kikuyu customs. On August 29, he wrote a letter to the East African Standard saying that "the missionaries have tried on many occasions to interfere with the tribal customs and the question is asked whether circumcision being the custom of the Kikuyu Christians, he is to be a heathen simply because he is a Kikuyu." 37

The missionaries now redoubled their efforts to gain influential outside support. The East African Women's League (the settler women's organization) and the Convention of Associations, alarmed at what they termed "seditious tendencies among a section of the natives," both passed vigorously worded resolutions condemning the custom. 38

The P.K.P. and the leading chiefs supported Arthur, and the elders of the C.S.M. stations were encouraged to prepare a petition to the Government, asking that it introduce the necessary legislation to ban the custom. On September 19, 1929, the last draft of the petition was approved, and the business of collecting signatures begun. At a Sunday service at Thogoto the statement was read and signatures invited. It was here that Johanna Karanja and

\section{7}

Tignor, Cultural Transformation, p. 242; from the Church of Scotland Memorandum prepared by the Kikuyu Mission Council on Female Circumcision, December 1931 , p. 42 . 
Ng'ang'a Ngoro, speaking for the young, broke with the mission. "I was a Christian," Ngoro said, however, "if the choice lay between God and circumcision, we choose circumcision. But it is a false European choice." 39 The K.C.A. leaders argued that nowhere in the Bible was there any reference to this matter. This then must be Dr. Arthur's Eleventh Commandment, they said, and since they had joined God's church and not Dr. Arthur's, they did not have to abide by his rules. 40

While much the same took place at the A.I.M. stations, many C.M.S. loyal members were willing to subscribe to the statement condemning circumcision. The C.M.S. had earlier problems with its converts, and by 1929 had expelled most of its K.v.A. members. Nevertheless, at the C.M.S. station at Kihumbuini, hostile demonstrations occurred during church services. On September 19, W. Knapp refused communion to those members not willing to sign a paper abjuring the custom. 41 Despite difficulties in the C.M.S. and A.I.M. stations, a number of persons at Kambui and Githumu stood loyally with the church. This proved enormously persuasive to Arthur. Increasingly, he became convinced that the church had grown slack and was harboring irreligious and disobedient elements who were attracted to the missions

\section{9}

40 Ibid., p. 119.

Leakey, Mau Mau and the Kikuyu, p. 89. 41

Tignor, Colonial Transformation, p. 243. 
only because of the education and economic advantages it offerred. In his view, the Kikuyu churches needed revival and purging, an effort that appealed to the strong revivalist tendencies in the A.I.M. and G.M.S. ${ }^{42}$

At this point Arthur took what was probably the most decisive step in the escalating crisis, as he embarked on a veritable revivalist crusade from september 24 to october 2 through the Kikuyu and Embu reserves. Taking with him Samsoni, a hospital worker for twenty years, Samuel Gitau, and a leading.C.S.M. elder, he held large and long meetings in the fashion of Christian evangelical crusades, speaking himself against the evils of female circumcision.

This tour politicised the dispute and caused the K.C.A. and others to intensify their opposition to the unyielding stance of Arthur. After a mild meeting at the C.M.S. station at Weithaga, he received a hostile reception at Kahuhia. "When I finished, natives at once became aggressive, several Bolshevist looking individuals trying to take the lead and fighting for the floor. Why was it I wanted to add to the Ten Commandments and who had given me the authority to do soj" 43 and "there was a pretty hot time and I realized what some of these association people could be like, the very evil of the thing showing in their faces." 44 The meeting

\section{2 \\ 43 Ibid., p. 243.}

Rosberg and Nottingham, "Mau Mau", p. 120; from Arthur's "Safari Diary," file on Female Nutilation (PCEA, Nairobi). 44

Tignor, CQI ornial Transformation, p. 243; from Oldham Papers, November 17, 1929, Box 247, London. 
broke up in disorder, and Arthur commented that the "spirit of indiscipline and absolute devilment must be exorcised somenow. I see no alternative to the strong, ruthless hand." 45

The ultimate destination of Arthur's evangelical crusade was Chogoria, a C.S.M. station in Embu district. Its director, Dr. Clive Irvine, complained that hospital dressers trained at Tumutumu were spreading K.C.A. ideas among the people and wanted Dr. Arthur to advise him on the situation. At Chogoria, Arthur stated the issue in plain terms:

"I gave the reasons why both circumcision and the K.C.A. must go. There could be no discussion: it was an order. The Church has made its laws: it would not go back. The K.C.A. had made the law the test of the allegiance of its followers: it had joined issue with the church and therefore they now must choose the Ghurch or the K.C.A. 46

While Arthur was at Chogoria, he devised the momentous vow or "promise paper,". as it was described in the C.S.M. Kikuyu News. The vow read: "I promise to have done with everything connected with circumcision of women because it is not in agreement with the Things of God and to have done with the K.C.A. because it aims at destroying the Church of God." 47 The Church debarred those

\section{5}

46 Ibid., p. 243.

Rosberg and Nottingham, "Mau Mau", p. 120; from Arthur's "Safari Diary," file on Female Mutilation (PCEA, Nairobi).

Tignor, Colonial Transformation, p. 244. 
those who would not ascribe to the vow from attending the mission schools, or from allowing their children to attend the schools. Opposition to this view appeared almost immediately. Church membership fell from one hundred and twenty persons to fourteen persons overnight, but Arthur viewed this as a success. "Chogoria's pentecost and revival had come... The spirit of the Scottish Covenenters was with us." 48 so possessed was he by the spirit of his crusade that he could even write in anger that:

Joseph Kangethe and Johnstone Kenyatta deserve to be hanged. The Kikuyu Church is the next for testing and Kahuhia and Weithaga, to say nothing of Embu and Kabete will never be right until they too are made to face their church members with the choice of two masters. 49

While the C.S.M., A.I.M., and G.M.S. were adament and uncompromising on the issue, neither the Roman Catholics nor the C.M.S. were disposed to support such an inflexible attitude. In fact, the C.M.S. elders at Kabete were inclined not to publicize, let alone sign the petition. 50 In September 1929, at Kahumbuini, a Communion service broke up in confusion because W.P. Knapp had refused Communion to all those who had not signed the declaration of loyalty to the Church.

The country was now in turmoil. Many rumors were spreading, including one that Europeans, whether missionaries, settlers, or administrators, opposed the circum-

48

Rosberg and Nottingham, "Mau Mau", p. 121; from Arthur's "Safari Diary". 49

50 Ibid.

Ibid. 
cision of girls only so that they might marry them and obtain control of the land. 51 The native population was splintering into factions süch as "Karing'a" (Pure Kikuyu) and "Kirori" (thumb-print, or sign), and those who had signed the declaration of loyalty were subject to abuse.

Not content with simply requiring converts to take the anti-circumcision oath, Arthur now required it also from the teachers and administrators in the reserves. In October 1929, every teacher of the C.S.M. had to sign a declaration of support of the mission's position on female circumcision and their non-membership in the K.C.A. Thirty-six teachers signed, five agreed to make a verbal declaration, but twelve teachers refused and left C.S.M. employment. 52 The Church elders of the C.S.M. were also asked to make a declaration of loyalty, but unlike the teachers, they could still retain their membership in the K.C.A. Of the fifty involved, sixteen refused to sign. The result of this action was that almost every single C.S.M. outstation was closed. The natives refused to accept any teacher who had signed the oath while the mission leaders were unwilling to employ agents who had not. On November 9, under pressure from the Government, Arthur resigned the seat that he had held on the Governor's

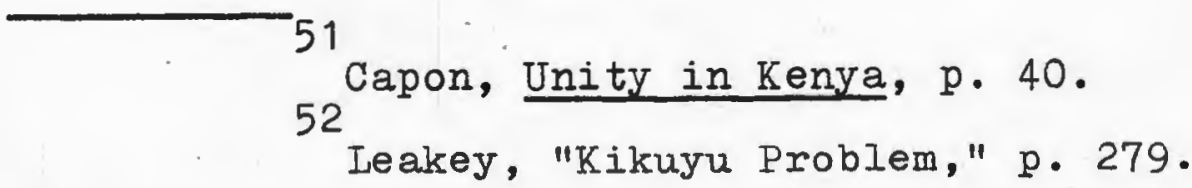


Executive Council. His uncompromising attitude on the circumcision issue had acutely embarrassed the Government, who believed that many Kikwy were coming to look upon him as a official Government spokesman. 53

The circumcision vow had produced the very result that the Kikuyu Christians had feared, namely a further fragmenting of the Kikuyu into antagonistic groups. The Churches lost as much as nine-tenths of their membership, and it was to take three or four years before they returned to the numerical strength of 1929. The break with the missionary churches was led mainly by the younger Kikuyu, while the older natives, who had close personal relations with the church and enjoyed the confidence of the missionaries, tended to remain.

By the end of 1931 church attendance had substantially recovered, but neither mission nor governmental authority could any longer command the respect it once possessed. "Individuals could no longer (accept) as a matter of course decisions of Administrative Officers or judgements of Magistrates but (were) only too ready to appeal against either." 54 In particular, the dominant mission role in education was no longer considered sacred. Missions had sought to use the Kikuyu desire for education as a means for promoting religious, social, and political ideas which

\footnotetext{
53

Capon, Unity in Kenya, p. 40.

"Native Affairs Department Annual Report," Great Britain House of Commons: Sessional Papers ( 1930), XXII, p. 4 .
} 
they considered desirable. They had threatened their students with the closing of schools if they did not conform to the mission point of view. The female circumcision controversy had thus casued a major educational crisis in central Kenya by 1931.

The independent church and school movements, which resulted from the controversy, were openly opposed to any interference or intervention by the missionaries. These movements reflected the growing nationalist and anti-European feelings of the young political leaders of the K.C.A., whose attempts to gain a rediess of African grievances had been reportedly frustrated. 
THE EMERGENCE OF THE KIKUYU INDEPENDENT CHURCH AND SCHOOL MOVEMENTS

While the Kikuyu independent church and school movement expressed in a general fashion the educational aspirations and discontent of families involved in missionary education, it was organized and carried to fruition by young edúcated men who had been alienated from the missions, largely through their involvement with the K.C.A. These men had seen the attack on female circumcision as extraneous to the doctrines of Christianity. The missionaries themselves were not even united on the issue, and the efforts of a few-to impose their beliefs upon the entire population were seen as unreasonable. Apart from the female circumcision controversy; however, there were several other reasons for African discontent with missionary education by 1930. Through the establishment of independent churches and schools, it was hoped that the Kikuyu would be able to develop their own talents free from missionary restraints. Many Kikuyu had been forced to withdraw or had withdrawn of their own accord because of the strictness of church law. Missionary influence had not confined itself to Gospel teaching or academics, but encompassed all areas of Kikuyu life. It was the inflexibility of Christian attitudes, especially in areas of morality, which was one reason for the break with the established missions. 
Many Kenyans who were members of the K.C.A. also felt that they could no longer remain in the mission churches. Further, there were many more natives who had signed Arthur's "promise paper," in which they pledged non-support of female circumcision and the K.C.A. in order to secure the continuation of their childrens' education, yet were secretly sympathetic to K.C.A. activities. Many of these people desired an alternative form of education to the mission schools and eagerly anticipated the establishment of alternative schools and churches.

Another reason for the break as that although the mission was an institution which employed many Kikuyu teachers, clerks, and evangelists, progress into positions of authority was exceedingly slow. An African could be a teacher in a mission school, but rarely a deadmaster. He could become a deacon of a mission church, but not a bishop. The independent churches and their schools would make possible an unimpeded rise to leadership by those Africans who proved their ability.

As a result of the crisis of 1929, and the growing Kikuyu desire for more and better education free from missionary constraints, there emerged two independent school movements-the Kikuyu Karinga Schools and the Kikuyu Independent School Association. The former was to become associated with the African Orthodox Church, while the latter was to establish the African Independent Pentecostal Church. 
The Karinga movement was closely associated with those who had broken with the C.S.M. at Kiambu. ${ }^{1}$ According to Johanna Karanja, who had become the movement's president in 1932, the name "Karinga" was chosen to emphasize their complete break with the Kenya missions. "Karinga" denoted tribal purity and those who supported the old tribal customs. Karinga schools were secular, radical, and antiEuropean in ideals. They stressed traditional Kikuyu customs like female circumcision, and shunned government conttact. $^{2}$ During the next twenty years, the Karinga movement fostered small schools in different parts of Kikuyu country, in Forest Department $\forall i l l a g e s$, on the Rift Valley farms, in Kisii and Kipsigis in the west, in Moshi and Arusha in northern Tanganyika, and at the olenguruone settlement in the Masai territory. ${ }^{3}$ Its main headquarters, however, remained the southern and western part of Kiambu District. The second educational movement that grew out of the female circumcision controversy was the Kikuyu Independent Schools Association (K.I.S.A.). As independent schools began to spring up in Kikuyuland at this time, an organization was needed which would contain and express the interests of the schools in each district, and speak to the Government and the missions with the strength of a united body.

"Department of Education Annual Report," Great Britain House of Commons: Sessional Papers (October, 1936), IX, p. $5 \overline{3}$.

F.B. Welbourn, East African Rebels: A Study of Some Independent Churches (London: S.C.M. Press, 1961), p. 168. Rosberg and Nottingham, "Nau Mau", p. 126. 
By 1934 the movement was formalized into the K.I.S.A., a loose confederation of independent schools located mainly in Fort Hall and Nyeri. ${ }^{4}$ The objects of the K.I.S.A. were "to further the interests of the Kikuyus and its members in matters relating to their spiritual, economic, social, and educational upliftment." 5 The K.I.S.A. sought education within a Christian environment, yet outside white control. The movement, however, quickly realized the need for an ordained ministry to baptize converts and perform other sacramental duties, since natives who attended K.I.S.A. schools were not allowed to attend mission schools.

After a discussion with the District Commissioner, the K.I.S.A. Independent Schools Committee of Fort Hall, under the leadership of Daudi Maina Kiragu, wrote in July 1933 to the Bishop of Mombasa, asking him to allow two of their men to undergo theological training. Alarmed at this, a special conference of all missions in the Fort Hall area took place at Kahuhia from October 13 to October 16, 1933. Faced with the imminent danger of the formation of an independent African church, the Conference members disregarded their previous "spheres of influence" policy and recommended that the C.M.S. should appoint an African minister to the Fort Hall area and should also consider

\footnotetext{
"Department of Education Annual Report," $\frac{\text { Sessional Papers, }}{5}$ (October, 1936), p. 55.

Rosberg and Nottingham, "Mau Mau", p. 127; from the Report and Constitution of the Kikuyu Independent Schools Association, (Nyeri, 1938), p. 3 .
} 
Independent candidates for theological training. These recommendations were subject to the Fort Hall Independent Schools Committee's assurance that they would not form an independent church, and that their men, when ordained, would be subject to the Biship's authority and would obey all the rules of the Church of England. 6

The conference approved these proposals on October 24 . However, further negotiations on the matter were subject to a misunderstanding. The C.M.S. representatives were under the impression that the agreement applied to all K.I.S.A. schools anywhere in Kikuyuland, whereas the C.S.M. thought that the agreement applied only to the Fort Hall area. The churches met at Nairobi in 1934 to sort the problem out but could come to no agreement. Meanwhile, because of the long wait, the Independent Schools' position had hardened and now included propositions that a churcin connected to the schools must be called the Kikuyu Independent Church and that no laws regarding circumcision could be laid down by the C.M.S. ${ }^{7}$

The independent churches forming the K.I.S.A. thus were becoming less interested in resuming links with the missionary churches, especially since by the mid-1930s another option seemed to be available. In late 1932 Archbishop Daniel Alexander of the African Orthodox Church

\footnotetext{
7 Ibid., pp. 127-128.
}

Ibid., p. 129; from a Confidential Circular to the Nembers of the Allied Missions from the Bishop of Mombasa, (January 4, 1935), "File on Female Mutilation," PCEA, Nairobi. 
in Mombasa agreed to come to Kenya in order to train and ordain an African clergy for the K.I.S.A. ${ }^{8}$ He arrived in 1935 and remained nearly eighteen months, baptizing, teaching new converts, and training a priesthood.

Alexander's arrival initiated a period of cooperation between the K.I.S.A. and the Karinga Schools. In 1937, the Archbishop ordained four students-Philip Kiande, Arthur Gatungu, Harrison Gacokia, and Daudi Maina Kiragu. ${ }^{9}$ Gacakia and Kiragu became ministers in the newly established African Independent Pentecostal Ghurch, which was to be affiliated with the K.I.S.A., and Gatungra formed the African Orthodox Church, associated with the Kaxinga Schools. When Alexander left Kenya in 1937, he left behind him an ordained African clergy functioning outside the auspices of any Kenya mission. The Kikuyu are by tradition a very religious people, and for many who no longer placed their faith solely on ancient tribal religion and who did not wish to subject hemselves to some of the stricter rules of conduct laid. down by the established missions, these new independent churches provided exactly what they wanted - a means of religious expression and commmunal worship which did not deter them from some of their tribal customs which they wished to retain. Each of these separatist or independent church movement sought to interweave or syncretize Christianity-

\footnotetext{
The Orthodox Church in Africa is reputed to have been closely affiliated with Marcus Garvey's Universal Negro Improvement Association. 9 Rosberg and Nottingham, Mau Mau, p. 130.
} 
particulary that of the old Testament-with valued and important aspects of traditional belief and practice. 10

Although no overall unity existed among the various African independent groups, the K.I.S.A. and the African Independent Pentecostal Church soon expanded their influence in Kiambu, Fort Hall, and Embu districts, and in the eastern part of the Rift Valley Settled Areas. 11 Concerned primarily with educational and religious matters, the K.I.S.A. sought to provide an African answer to problems of social development and spiritual needs. 12 In the political conflicts of the late 1940s and early 1950s, the K.I.S.A. was to become a divided movement, with the majority ultimately supporting militant nationalism.

The Karinga movement represented a more politically oriented approach to the solution of its problems. The degree of disillusion and dissent seems to have been higher within the Karinga movement than with the K.I.S.A., in part reflecting the differences in the rate of social change between southern Kiambu; the center of the Karinga movement, on the one hand, and north Kiambu, Fort Hall, and Nyeri (K.I.S.A. areas), on the other. ${ }^{13}$ In contrast 11

Leakey, Mau Mau From Within, p. 38. 12

Rosberg and Nottingham, "Mau Mau", p. 130. 13 Ibid., pp. 130-131.

Ibid., p. 131. 
with other Kikuyu areas, the impact of social change in southern Kiambu had been more abrupt and intense; moreover, anxiety arising out of the loss of land was more widespread. Members of the Karinga movement were more closely touched by land issues, and the only solution was seen to be political action.

The independent churches and schools were to face many setbacks during the next twenty years. The longterm effects of the female circumcision controversy went far beyond any question of the successful establishment of an Orthodox or Pentecostal Church or an independent school system. During the controversy of 1929 many Kikuyu had begun to question the direction of social change and its effects on their indigenous culture. Mission education was not seen as a training for independence, but for subservience. 14 As a result of the female circumcision controversy, the natives demanded the right to selective modernization; this was the basis for the Independent church and school movements, and was to be the catalyst.of the nationalist ideology of the future Kikuyu political movements.

14 Welbourn, East African Rebels, p. 43. 


\section{CONCLUSION}

Only recently has the popular Western image of the "Mau Mau" revolts, which lasted from 1952 to 1960, as a "barbarous, atavistic, and anti-European cult whose leaders planned to turn Kenya into a land of darkness and death". ${ }^{1}$ been seriously questioned. Indeed, many modern scholars have revealed that it was the tightening grip of white domination which precipitated the violent reaction. "Mau Mau" was the culmination of an ongoing, rationally conceived nationalist movement which was born in response to the events of 1929.

Popular opinion in the 1950 's and early 1960 's was that the revolts were mainly the product of the Kikuyu peoples' failure to adapt fully to the demands of rapid modernization. This statement is not completely true. Rather, it was the missionary demand for the total social and cultural transformation of Kikuyu society in a relatively short period of time which was the real cause of native discontent. The missionaries did not adhere solely to their principal vocation, that of converting the natives to Christianity, but insisted also on adapting native culture and society to conform to European standards. Thus in East Africa there evolved another missionary goal-that of Westernizing the indigerious population.

Martin Lowenkopf, "Upheaval in Kenya," New Republic 156 (February 25, 1967): p. 34. 
Missionary presence in Kikuyuland in the early part of the twentieth century caused a fragmentation of the native population into three main groups. There were those who followed mission teaching, rigidly and unequivocally: This group was seen by the majority of the population, not as converted natives, but essentially as "black Europeans." These converts frequently took a Christian name upon baptism and aspired to employment in the service of the mission or the colonial government. As a result of the circumcision controversy, these converts were frequently ostracized from their families, and had little social acceptance from the tribe. The second group consisted of those who rejected Western education and Christianity. and insisted on a return to the ancient tribal customs and culture. Finally, there was the majority of the natives, who accepted Christianity and welcomed Western education, primarily because they saw that this was the means by which they could obtain secure and desirable employment. This group, however, wanted a selective type of change, or at least, a gradual modernization.

The missionaries were almost incapable of seeing anything positive and valuable in the life and culture of the African, and were trained to apply derogatory labels to him and his culture. The Kenyan political leader, Tom Mboya, once said that he "could not recall a missionary fighting back and denouncing the colonial regime and 
social setup, or trying to create among Africans a new spirit of pride and confidence in themselves. Rather, they undermined this confidence by a negative attitude. ${ }^{2}$ It. was missionary insistence on imposing their own standards of morality upon the natives which was to lead to the female circumcision controversy. The missionaries could not rethink their Christian ethics in order that they may be more easily accepted in a culture which was so different from their own. When they discovered that their African supporters and congregations were mostly unwilling to accept such dramatic and immediate changes in their lifestyles, instead of trying to form a compromise, they applied the most powerful sanctions at their disposal. They suspended most of their converts from church services and closed the schools they were running.

The development of the Kikuyu nationalist movement arose out of two main premises. The first was a reaction to the missionary desire to eradicate all the bad and "perverse" ancient Kikuyu traditions and institutions, especially the initiation ceremony. The Kikuyu argument was not in the defense of the actual surgical operation, but in the understanding that the operation was regarded as the very essence of the institution of initiation; an institution which had enormous educational, social, moral, and religious implications, quite apart from the operation itself.

Tom Mboya, Freedom and After, (Boston: Iittle, Brown, and Company, 1963$), \mathrm{pp} \cdot 10-11$. 
Among the Kikuyu the circumcision of girls as well as boys formed an important part of the initiatory rites associated with age-sets and entry into fuli membership in the tribal community. It was looked upon as a deciding factor in giving a boy-or girl the status of an adult. Female circumcision was the outward symbol of a girl's reaching the end of her education and marked her readiness to indulge in sexual activities. It was impossible to imagine an initiation ceremony without clitoridectomy. Therefore the abolition of the operation meant to the Kikuyiu the abolition of a whole institution. 3

The second reason for the development of Kikuyr nationalism was the swift and total transformation of native society demanded by the missionaries. The missionaries prevented any possibility of selective change, by which some elements of Western culture might be absorbed by the Kikuyu, while others might be rejected as unacceptable to their values. Rather, Western culture and Christiarity were identified together as an integral corpus of belief and practice; the rejection of one element in the whole was seen as a total rejection of the whole. The capacity of the Protestant missionary movement not to budge an inch from its principles and its prejudices was only paralleled by the African's inability or desire to assimilate into his culture all the changes demanded of him. The missionMurray-Brown, Kenyatta, p. 128. 
aries should have realized, but did not, that tradition does not move overnight without a disturbance of social and individual balance.

As we have seen, the forces of Kikuyu nationalism called themselves the Kikuyu Central Association. By 1939 the K.C.A. had a paid membership of two thousand, though the actual number of supporters was much higher. The Teachers Training College at Githuguri, in the Kiambu district, was established largely through K.C.A. influence. The College was open to students of all Kenyan tribes, and was seen to be a model of African solidarity and inter-tribal cooperation.

There is no question that the power and influence of the K.C.A. was on the rise when, in May 1940, it was declared an illegal society, largely on the pretext that it was in contact with the King's enemies in Ethiopia. 4 Its offices in Nairobi were closed, its newspapers suppressed, most of its prominent leaders were removed, and the K.C.A. was driven underground.

World War II had the effect of greatly accelerating all the native problems. The post war era brought economic pressures, rural and urban unemployment, and overused land. Soil and cattle conservation became controversial issues. Some Europeans had permitted the Kikuyu to cultivate and graze on their lands. In 1945, more rigorous administration of these squatter agreements brought about areduction in the number of cattle and areas for cultivation allowed to 
Africans. This forced many African squatters to leave European farms and return to the reserves. These "dispossessed" Kikuyu who returned to the already overcrowded reserves were very receptive to Nationalist ideas.

Many young African men who served in the British forces were exposed to new attitudes and ideas while abroad fighting against the Italians, Japanese, and Germans. When they returned home, they became imbued with many new ideas and theories about what rights they should claim in their own country. They became trained in various skills, many of which were not marketable in Kenya on their return. Some of those unemployed became interested in politics as a means of achieving their goals. Anumber of returned servicemen became members of the "Forty Group" (Anake a $\underline{\text { 40) }}$ which helped to bring about changes in the African situation. 5

The Government system became more and more bureaucratic after the War. The European community demanded more and more voice in the governing of the country, and gained a good deal in this direction. The Africans, on the other hand, were given a small, but quite inadequate representation in Government councils and official bodies.

Neither the government of the colony.nor of Great Britain realized the impending crisis. By this time, the Africans realized that the government was really not concerned with the demand for political reform. The possibility of achieving political development through pro-

Rosberg and Nottingham, "Mau Mau", p. 240. 
portionate and direct representation of the Africans beeame increasingly remote. As a result those persons who advocated violence and direct confrontation increasingly gained support. 6

The female cireumcision controversy thus had been a warning of future troubles. It provided, as it were, a dress rehearsal for a later nationalist movement which had come to be known as "Mau Mau." Essentially, the causes of Mau Niau were the same as those of the controversy of 1929: the breakdown of tribal culture and rapid industrialization. At first Africans had sought to obtain redress for their grievances within the framework of the settler-oriented state; following world War II, however, many came to challenge its very legitimacy. A nationalism of petition and constitutional protest gave way to a militant nationalism employing direct action in seeking a new social order. 7 Political violence led to the Declaration of an Emergency in October 1952. At first violence and later reform characterized the seven year ordeal of the Emergency, culminating in dramatic changes in British policy in 1960.

The years under study were important not simply because they provided a valuable example of the practice of British colonial policy, but also because they marked the beginning of a vital period of change in the lives of the African peoples themselves. The increasing demands of

Rosberg and Nottingham, "Mau Mau", p. 240. 7 Ibid., p. 233. 
British rule meant that the old tribal life could never be quite the same again. For this reason an attempt has been made in these pages to indicate some of the ways in which the demanos of the new rulers came to be felt. Then, more particulary, some of the African reactions to these demands have been shown. For in the final analysis, the establishment of the colonial administration cannot be understood simply in terms of the forceful imposition of British rule. It mast also be seen in terms of African rejection or acceptance of the new regime. 


\section{BIBIIOGRAPHY}

Barnett, DonaId I. and Njana, Karari. Mau ivau From iithin. New York: Wonthly Review Press, 1966.

Bewes, T.F.C. "Work of the Christian Church Among the Kikuyu." International Affairs 29 (1953): 316-25.

Cagnolo, Fr. C. The Akikuyu. Nyeri: The lission Printing School, 1933.

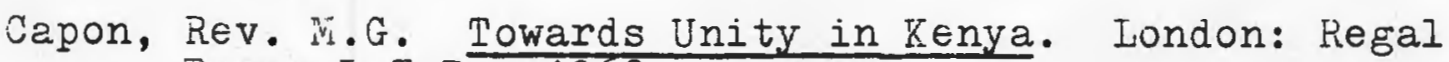
Press I.T.D., 1962 .

Dunàas, H.R. "Kikuyu Calenāar." Wan 9 (1909): 37-38.

Gann, L.i. and Duignan, Peter, eds. Colonialism in Árica 1870-1960. VoI. II: The History and Politics of Colonialism 1914-60. Cambriage: vambridge University Press, 1970.

Great Britain. House of Commons. Parlianentary Debates, December 11, 1929. CCXXXIII, pp. 588-592. ("CoIonial Policy-Coloured Races.").

- Parliamentary Debates, December 23, 1929, CCCXXXIII, p. 1248. ("Written Áswers.").

Great Britain. House of Commons. Sessional Yapers, April 1925, IX, pp. 1-52. ("Report of the East African Commission.").

- S'éssional Papers, viarch 1926, XXI, pp. 2-65. ("Educational Policy in British Tropical Africa; liemorandum Submitted to the secretary of State for the Colonies by the Advisory Committee on Native Eaucation in the Brtiish Tropical Dependencies.").

- Sessional Papers, 1926 XXI, pp. 1-34. ("Conference of Governors of the East African DependenciesSummary ô Froceeāings." ).

- Sessional papers, 1930, XXII, pp. 1-29. ("Native HIfairs Department innual Report.").

- SessionaI Hapers, October 1933, XI, pp. 1-29. (Native Affairs Department Annual Report.").

- "Sessional Eapers, 1936, IX, pp. 20-63. ("Department of Education Annual Report."). 
Guma, S.M. "Circumcision Basutoland." African Studies $24(1965): 241$.

Hobley, C.W. Bantu Beliefs and Magic. New York: Barnes and Noble, 1967.

Kenyatta, Jorno. Facing Hount Kenya. New York: Vintage Books, 1962.

Lambert, H.E. Kikuyu Social and Political Institutions. London: Oxford University Press, 1956.

Leakey, L.S.B. "The Kikuyu Problem of the Initiation of Girls." Journal of the Royal Anthropological Institute of Great Britain and Ireland 61 (1931): ट77-285. - Company I.T.D., 1953. London: viethuen and

- Kenya: Contrasts and Problems. Cambridge:

Schenkman Publishing Company, Inc., 1972.

- The Southern Kikuyu Before 1903. 3 vols. Iondon: Academic Press, 1977.

Lowenkopf, Martin. "Upheaval in Kenya." New Republic 156 (February 25, 1967): 34-35.

Mboya, Tom. Freedom and After. Boston: Little, Brown, and Company, 1963.

VicGlasien, N. "Kikuyu Iaucation." African \&ffairs $02(1963): 47$.

Massam, J.A. Ine Cliff Iwellers of Kenya. Iondon: Frank Cass and Company, I.T.D., 1968.

Middleton, John and Kershaw, Greet. The Central Tribes of the Norti-Eastern Bantu. Fast Central Africa Series of the Ethnographic Survey of Africa. Eondon: International African Institute, 1965.

Hoorhouse, Geoffrey, The Wissionaries. Fhiladelphia: J.B. Iippincott Compary, 1973.

Hungean, G.H. British Rule in Kenye 1895-1912. Oxford: Ularendon Fress, 1966.

Jurray-Brown, Jeremy, Kenyatta. New York: E.P. Dutton and Company, Inc., 1973.

Oliver, Roland. The liissionary Factor in East Africa. 2nd ed. Iondon: Lon jomans, Green and Company, I.T.D., 1965 
Oliver, Roland and Fage, J.D. A Short History of Africa. Baltimore: Penfuin Books, 1962.

Rosberg, CarI G. and Nottingham, John. The Myth of Mau Mau": Nationalism in Kenya. New York: Frederick A. Praeger, Pubs., 1966.

Strayer, Robert $W$. "The Dynamics of Mission Expansion: A Case Study from Kenya, 1875-1914." Journal of African Historical Studies 6 (1973): $2 \overline{29-248 .}$

Tate, H.R. "The Native Law of the Southern Gikuyu of British East Africa." Journal of African Society $110(1911)$ : 285-297.

Tignor, Robert L. The Colonial Transfermation of Kenya. Princeton: Princeton University Press, 1976.

Ward, W.E.F. and White, I.W. East Africa: A Century of Change 1870-1970. New YOrk: Africana Publishing Corp., 1972.

Welbourn, F.B. East African Rebels: A Study of Some Independent Churches. Iondon: S.C.M. Press, 1961. 